\title{
Expected Future of Water Resources within Tigris-Euphrates Rivers Basin, Iraq
}

\author{
I. E. Issa ${ }^{1,2}$, N. A. Al-Ansari', Govand Sherwany ${ }^{3}$, S. Knutsson ${ }^{1}$ \\ ${ }^{1}$ Department of Civil, Environmental and Natural Resources Engineering, Luleå University of Technology, Lulea, \\ Sweden \\ ${ }^{2}$ Department of Dams and Water Resources Engineering, University of Mosul, Mosul, Iraq \\ ${ }^{3}$ Ministry of Higher Education and Scientific Research-KRG, Erbil, Iraq \\ Email: issa.elias@ltu.se, nadhir.alansari@Itu.se, govand.sherwani@mhe-krg.org, sven.knutsson@ltu.se
}

Received 4 March 2014; revised 1 April 2014; accepted 15 April 2014

Copyright ( 2014 by authors and Scientific Research Publishing Inc.

This work is licensed under the Creative Commons Attribution International License (CC BY).

http://creativecommons.org/licenses/by/4.0/

(c) () Open Access

\section{Abstract}

Iraq is one of the riparian countries within basins of Tigris-Euphrates Rivers in the Middle East region. The region is currently facing water shortage problems due to the increase of the demand and climate changes. In the present study, average monthly water flow measurements for 15 stream flow gaging stations within basins of these rivers in Iraq with population growth rate data in some of its part were used to evaluate the reality of the current situation and future challenges of water availability and demand in Iraq. The results showed that Iraq receives annually 70.92 $\mathbf{k m}^{3}$ of water 45.4 and $25.52 \mathrm{~km}^{3}$ from River Tigris and Euphrates respectively. An amount of $18.04 \mathrm{~km}^{3}$ of the Tigris water comes from Turkey while $27.36 \mathrm{~km}^{3}$ is supplied by its tributaries inside Iraq. The whole amount of water in the Euphrates Rivers comes outside the Iraqi borders. Annual decrease of the water inflow is $0.1335 \mathrm{~km}^{3} \cdot \mathrm{year}^{-1}$ for Tigris and $0.245 \mathrm{~km}^{3} \cdot \mathrm{year}^{-1}$ for Euphrates. This implies that the annual percentage reduction of inflow rates for the two rivers is $0.294 \%$ and $0.960 \%$, respectively. Iraq consumes annually $88.89 \%\left(63.05 \mathrm{~km}^{3}\right)$ of incoming water from the two rivers, where about $60.43 \%$ and $39.57 \%$ are from Rivers Tigris and Euphrates respectively. Water demand increases annually by $1.002 \mathrm{~km}^{3}$, of which $0.5271 \mathrm{~km}^{3}$ and $0.475 \mathrm{~km}^{3}$ are within Tigris and Euphrates basins respectively. The average water demand in 2020 will increase to $42.844 \mathrm{~km}^{3} \cdot \mathrm{year}^{-1}$ for Tigris basin and for Euphrates $29.225 \mathrm{~km}^{3} \cdot$ year $^{-1}$ (total 72.069 $\mathrm{km}^{3} \cdot \mathrm{year}^{-1}$ ), while water availability will decrease to $63.46 \mathrm{~km}^{3} \cdot \mathrm{year}^{-1}$. This means that the overall water shortage will be restricted to $8.61 \mathrm{~km}^{3}$.

\section{Keywords}

Iraq, River Tigris, River Euphrates, Water Resources of Iraq 


\section{Introduction}

Scarcity of water resources in the Middle East is one of the most important problems since the last century due to the increase of the demand and climate changes [1]-[7]. Historically, water had played a vital role at the dawn of the first civilization in the life of human kind. The first development of water resources and land goes back to the beginning of $5500 \mathrm{BC}$ in the basin of the Tigris and Euphrates Rivers known as the Mesopotamian. The Sumerians and Babylonians used water of Euphrates River to irrigate their fields and cities by systems of canals $[4]$.

Iraq started in 1950 planning for the construction of irrigation and flood control systems by the Board of Development created by the Kingdom of Iraq. Primarily, it was to protect Baghdad, the capital, and other major cities from flooding. The first big dam (Dokan) was constructed in 1959 on the Lesser Zab River. This was followed by the construction of other projects where many dams were constructed for irrigation and power generation purposes. In addition, a system was established on the River Euphrates to control its flood. This system includes Ramadi barrage and the Habbaniye Lake. Other systems on the Tigris River including regulators, canal systems, Lake Tharthar project and the Samarra dam were constructed [8] [9].

In the modern history, Iraq until 1970 was considered rich in its water resources due to the presence of the Tigris and Euphrates rivers. In mid-seventies Syria and Turkey started to build dams on the Euphrates River; therefore, its flow decreased due to water impounding of some of the new reservoirs [3] [10]. This fact forced the Iraqi Government to speed up building as much as they can from the planned hydrological projects. For this reason, 1970 to 1990 was the best period of the development of Iraq's water systems. The process stopped in 1990 due to the first Gulf War and UN sanctions. Through the last fifty years period, from 1960 to the end of the twentieth century, there was a change in the supply and demand situation. Table 1 summarizes the hydraulic structures on the Tigris-Euphrates Rivers.

In 1977, the Turkish Government started to utilize the water of the Tigris and Euphrates Rivers through the South-eastern Anatolia Project (GAP) [3] [10]. The project includes 22 multipurpose dams and 19 hydraulic power plants which are to irrigate $17103 \mathrm{~km}^{2}$ of land with a total storage capacity of $100 \mathrm{~km}^{3}$ which is three times more than the overall capacity of Iraq and Syrian reservoirs [3] [10]. Eight of these dams are to be constructed on the River Tigris, only three were built (two in 1997 and one in 1998). The irrigation projects within the GAP will consume about $22.5 \mathrm{~km}^{3} \cdot \mathrm{year}^{-1}$ after completion [3] [4] [10]. In addition, recent studies indicated that there will be more increase in the water demand in the Middle East and North Africa (MENA region). In 2050, water demand will reach up to $393 \mathrm{~km}^{3} \cdot \mathrm{year}^{-1}$. This indicates that the water shortage will be 193 $\mathrm{km}^{3} \cdot$ year $^{-1}$ of which $22 \%$ due to climate change and $78 \%$ to changes in population growth and economic development factors [6]. Furthermore, the studies on the Tigris-Euphrates Western Iran region show a total groundwater loss of nearly $144 \mathrm{~km}^{3}$ during 2003 to 2009 [7]. The reduction of flow in the Tigris and Euphrates Rivers in Iraq is considered to be a national crisis and will have severe negative consequences on health, environmental, industrial and economic development [4] [7] [10]. In view of the above, it became necessary to know the water resources trends in the Tigris-Euphrates rivers basin within Iraq. In the present study the current and future water situation (availability and demand) was evaluated using a new method. The method applied for that purpose was the use of monthly water discharges measurements for 15 stream flow gaging stations on the Tigris-Euphrates Rivers inside Iraq. Population growth data with annual water consumption per capita were used for the southern region of Iraq beyond the gaging stations. The water discharge measurements were used in the calculations due to the fact that it takes into consideration the water consumption due to different uses, infiltration and evaporation loses as well.

\section{Study Area}

\subsection{Hydrology of Tigris-Euphrates Rivers Basin}

The Tigris and the Euphrates rivers are the two important and greatest rivers of western Asia. The rivers originate from the same region in Turkey about $30 \mathrm{~km}$ from each other. The region is characterized by its cool and humid climate with a rugged land of high mountains and deep gorges. From there, the two rivers flow separately onto a wide, flat, hot, and poorly drained plain. In their middle path, the twin Rivers diverge hundreds of kilometers apart and join together near Qarmat Ali about $160 \mathrm{~km}$ above the head of the Gulf, forming the Shatt al-Arab (Figure 1). The upper basin of the rivers is characterized by the rock and mountain gorges of Anatolia 
Table 1. The constructed dams in the basin of the Tigris-Euphrates Rivers.

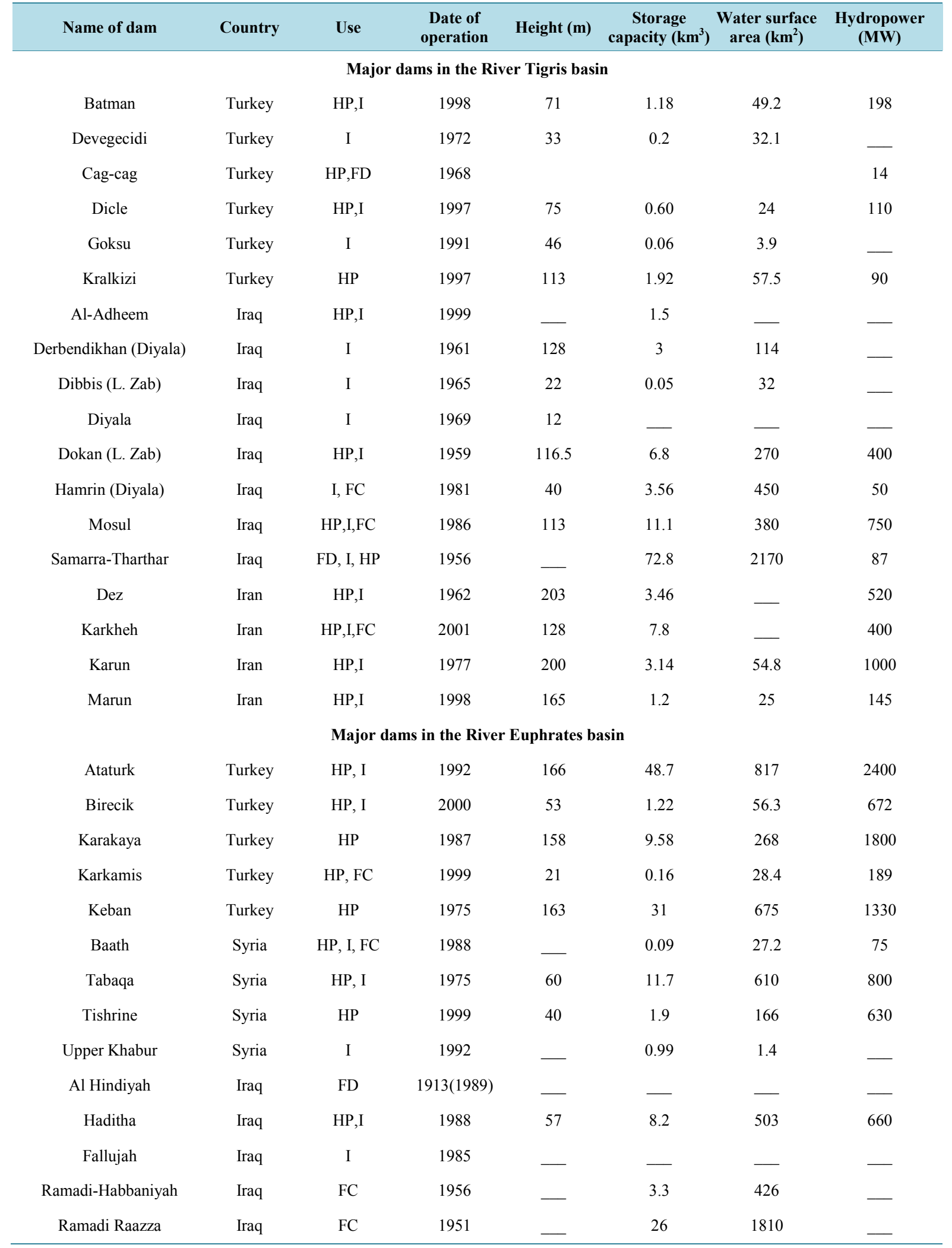

HP: hydropower; I: irrigation; FC: flood control; FD: flow division. Source: [8] [9]. 


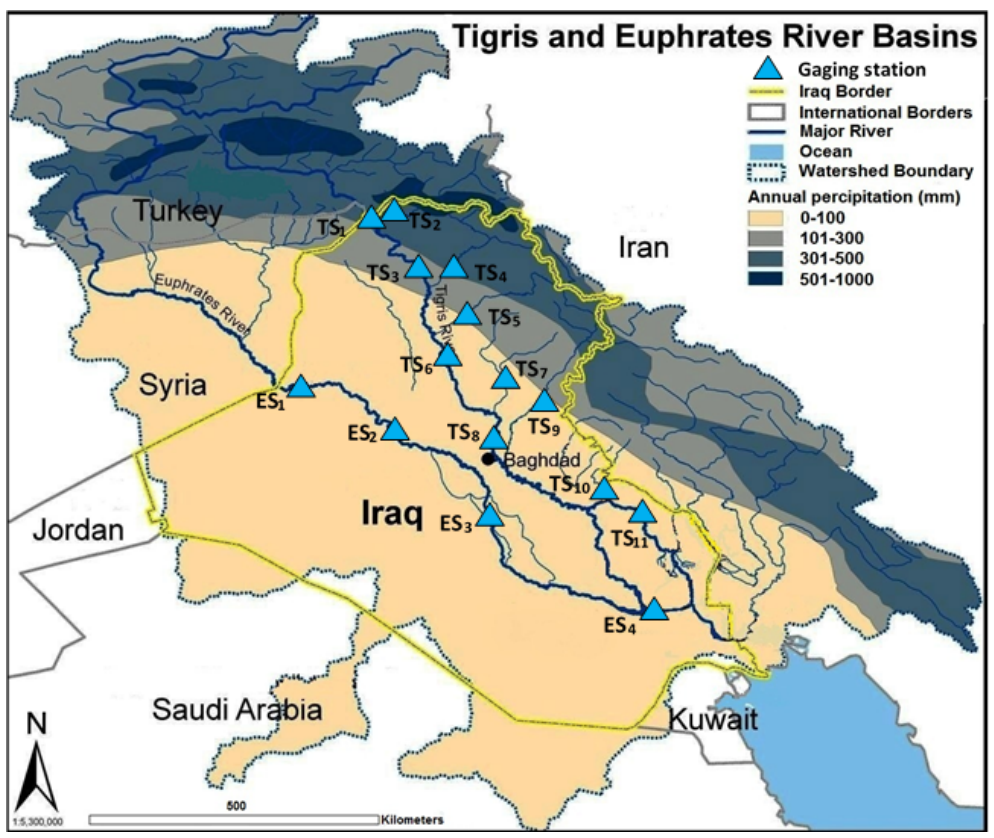

Figure 1. General layout of the Tigris-Euphrates Rivers and locations of stream flow gaging stations.

and the high plateaux of Syria and Iraq. The climate of the catchment area may be regarded as being similar to a Mediterranean climate except some differences due to the presence of a mountainous region which is located within the Turkish territory. The climate is a hot-dry summer and cold-rainy winter with occasional snowfall taking place in the mountain region. The precipitation in Mesopotamian basin occurs between October and May. The annual precipitation over the Tigris-Euphrates Rivers basin ranges between 100 and 1000 mm annually (Figure 1) [10]. The heaviest precipitation occurs from December to February. Generally, snow melting begins in February causing higher discharges during spring flows (March to May or early June). Low water discharges are usually during the hotter and drier summer months (July to October). During this period the main source of the rivers runoff is groundwater. The average monthly temperatures range between $6^{\circ} \mathrm{C}$ in January to $34^{\circ} \mathrm{C}$ in July but the temperatures decrease towards the north [3] [10]. The flow discharges vary to 10 times between flood season that occur during winter and spring due to the rain and snow melt and dry period during summer and part of autumn. Table 2 shows the details of contributions for riparian countries in the rivers basins.

\subsection{River Tigris}

River Tigris is the second-largest river in western Asia. The main source for the Tigris River is Hazar Lake (elevation $1150 \mathrm{~m}$ a.s.l), which is located in the south eastern region of Turkey. The lake is surrounded by the Taurus mountain chain where its height reaches $3500 \mathrm{~m}$. The headwaters of the Tigris River begin in the small mountain lake of Jazar Golu in Turkey; $30 \mathrm{~km}$ from the upper catchment of the Euphrates. The River flows in the hilly regions located to the south western portion of the mountainous area connecting Turkey, Iran and Iraq. The River Tigris flows directly towards Iraq and the Mesopotamian Plain with only a small part that is parallel alongside the Syrian border. The River crosses the Iraqi border at Faish Khabur village which is located about $400 \mathrm{~km}$ from the main sources [3] [10]. Eight major tributaries feed the Tigris River from the left bank three in Turkey before entering Iraq which are Batman, Garzan and Botan and five in Iraq are Khabur, Greater Zab (partly beginning in Turkey), lesser Zab, Uzaym and Diyala rivers (Figure 1). The tributaries in Iraq flow down from the north east of Iraq (Zagros Mountains) and join to the main river before Baghdad city [10]-[12]. The river drains an area about $375,000 \mathrm{~km}^{2}$ which is shared by Turkey, Syria, Iraq and Iran (Table 3). The total length of the river is about $1862 \mathrm{~km}$; only $21 \%$ of the length of the Tigris lies in Turkey and remainder lies in Iraq. According to most of previous studies; the mean annual flow of the Tigris from Turkey before it enters Iraq is ranging from 20 to $23 \mathrm{~km}^{3} \cdot \mathrm{year}^{-1}$. During its passage in Iraq the river receives from all of the above tributaries an additional amount of water that reaches 25 to $29 \mathrm{~km}^{3} \cdot \mathrm{year}^{-1}$ [10] [13]. The most significant features of the 
Table 2. The contributions in the Tigris-Euphrates Rivers basin for riparian countries.

\begin{tabular}{|c|c|c|c|c|c|}
\hline Tigris-Euphrates Rivers & Turkey & Iraq & Syria & Iran & Total \\
\hline Discharge $\mathrm{km}^{3} \cdot$ year $^{-1}$ & 65.7 & 6.8 & 0.5 & 11.2 & 84.2 \\
\hline Discharge (\%) & 78.1 & 8.1 & 0.5 & 13.3 & 100 \\
\hline Drainage Area km² & 170,000 & 469,000 & 77,000 & 37,000 & 819,000 \\
\hline Drainage Area (\%) & 20.5 & 46.0 & 9.0 & 19.0 & 94.5 \\
\hline Rivers Length (km) & 1630 & 2478 & 754 & - & 4862 \\
\hline Rivers Length (\%) & 33.5 & 51.0 & 15.5 & - & 100 \\
\hline Irrigable lands $\mathrm{km}^{2}$ & 24,270 & 40,000 & 9500 & - & 73,700 \\
\hline Irrigable lands (\%) & 33 & 54.2 & 12.8 & & 100 \\
\hline
\end{tabular}

Source: [8] [13].

Table 3. Characteristics of the Tigris River basin.

\begin{tabular}{cccccc}
\hline Tigris River & Turkey & Iraq & Syria & Iran & Total \\
\hline Discharge $\mathrm{km}^{3} \cdot \mathrm{year}^{-1}$ & 33.5 & 6.8 & 0.0 & 11.2 & 51.5 \\
Discharge (\%) & 65.0 & 13.2 & 0.0 & 21.8 & 100 \\
Drainage Area $\mathrm{km}^{2}$ & 45,000 & 292,000 & 1000 & 37,000 & 375,000 \\
Drainage Area (\%) & 12.0 & 54.0 & 0.2 & - & 100 \\
River Length (km) & 400 & 1318 & 44.80 & - & 1862 \\
River Length (\%) & 21.0 & 77.0 & 2.0 & - & 100 \\
\hline
\end{tabular}

Source: [8] [13].

River Tigris basin are given in (Table 3).

The mean annual flow of the Tigris River at Mosul city prior to 1984 was $22.2 \mathrm{~km}^{3}$ and dropped to $17.7 \mathrm{~km}^{3}$ [10]. The annual hydrograph for Tigris River starts from October to September. The highest mean monthly discharge takes place during April and the driest month is generally September (Figure 2).

\subsection{River Euphrates}

Euphrates is the longest river in western Asia. The majority of the water resources of the Euphrates are located in the Turkish territories of Anatolia. The river rises near Mount Ararat at heights of around $4500 \mathrm{~m}$ near Lake Van, the Euphrates is formed from two tributaries, the Murat-Su and the Kara-Sue (or Frat-Sue). The River flows southward to $160 \mathrm{~km}$ of the Mediterranean with average slope 2 meters per kilometer before it turns left into Syria to continue in a south-east direction, almost straight towards Shatt Al-Arab River [3] [4] [10] [13].

After the river enters the Syria's borders at Jarablis, within Syrian territories by two small tributaries join the river. They are Balikh and the Khabur Rivers that contribute with small amount of water to the Euphrates River (Figure 1). Euphrates enters Iraq at Hasaibah. Its annual flow at the Iraqi border is of the order of 28 to 30 $\mathrm{km}^{3} \cdot \mathrm{year}^{-1}$ [14] [15]. In Iraq, $360 \mathrm{~km}$ from the border, the river reaches a giant alluvial delta at Ramadi where the elevation is only $53 \mathrm{~m}$ a. s. 1 . From that point onward, the river traverses the deserted regions of Iraq, losing part of its waters into a series of desert depressions and distributaries, both natural and man-made. Euphrates has number of small tributaries in the central and southern parts of Iraq for irrigation purposes. No tributary contributes water into the river within Iraqi territories (Figure 1). The Euphrates has a very gentle gradient in Iraq. The characteristics of Euphrates basin tabulated in Table 4.

The most significant features of the Euphrates River at Hit and Haditha cities for the period 1932-1997 illustrate in Figure 3. 


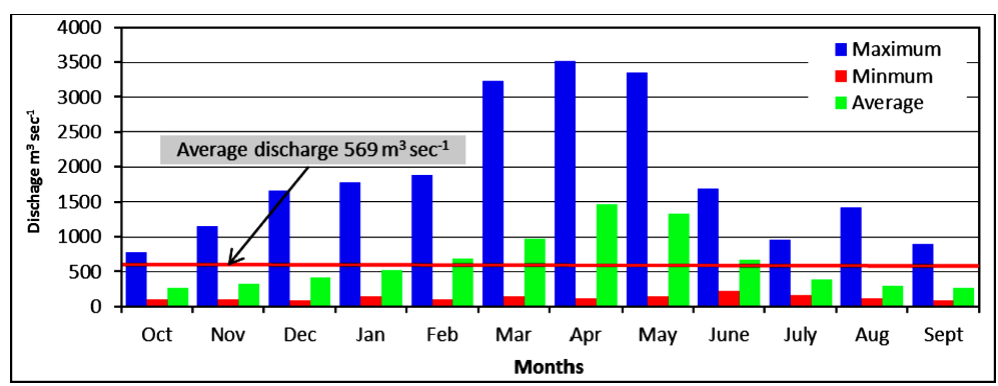

Figure 2. Monthly (mean, minimum and maximum) discharge of Tigris River at Mosul dam site (1931-2011).

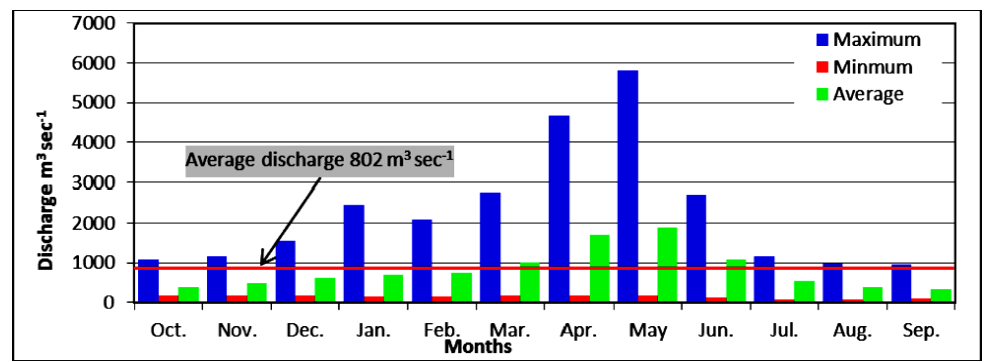

Figure 3. Monthly (mean, maximum and minimum) discharge of Euphrates River at Hit site (1932-1997).

Table 4. Characteristics of the Euphrates River basin.

\begin{tabular}{ccccc}
\hline Euphrates River & Turkey & Iraq & Syria & Total \\
\hline Discharge $\mathrm{km}^{3} \cdot \mathrm{year}^{-1}$ & 32.2 & 0.0 & 0.5 & 32.7 \\
Discharge (\%) & 98.5 & 0.0 & 1.5 & 100 \\
Drainage Area km & & 177,000 & 76,000 & 444,000 \\
Drainage Area (\%) & 125,000 & 40.0 & 17.0 & 85 \\
River Length (km) & 28.0 & 1060 & 710 & 3000 \\
River Length (\%) & 1230 & 35.0 & 24.0 & 100 \\
\hline
\end{tabular}

Source: [8] [13].

\section{Data and Methodology Used}

The water discharges records (Table 5) are very important to study the potential water supply and demand. For these purposes; the averages monthly discharges for 15 stream flow gaging stations within TigrisEuphrates Rivers basin in Iraq were used to evaluate the reduction in water availability and increasing water demand. These stations are 11 on the River Tigris (TS) and its tributaries and 4 on the River Euphrates (ES) (Figure 1 and Table 5). The data of these stations were adopted from Al-Shahrabaly [16] and Saleh [17]. The water discharges data were used to generate the Trend lines of the discharge versus time using excel program. The Trend lines were then used to estimate the reduction in water availability using their slopes. The increases of the demands however, were computed using Trend lines of water consumption for different regions within Tigris-Euphrates basin inside Iraq. The Trend lines of the demands were generated by differences in discharges measurements for successive stations along the same river. The areas in the south, where no gaging stations exist (see Figure 1, below gaging stations $\mathrm{ES}_{4}$ and $\mathrm{TS}_{11}$ ), the demands were computed using the population growth rates. This was carried out in 4 governorates in the southern part of Iraq (Al-Kut, Al-Amarah, An-Nasiriyah and Al-Basra) having $2616 \mathrm{~m}^{3} \cdot$ year $^{-1}$ annual water consumption per capita. The population growth rate data was provided by [18] (Figure 4) while the water withdrawal per capita was estimated by [19]. 


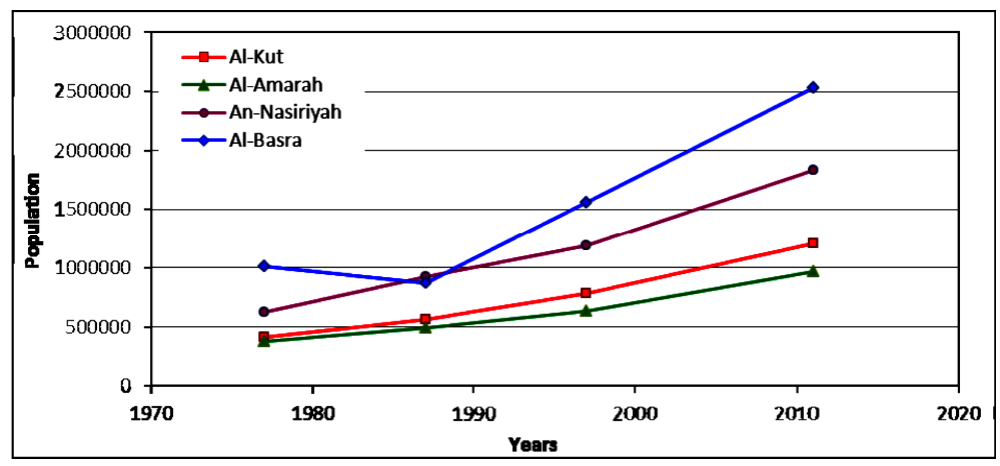

Figure 4. Population growth distribution for Al-Kut, Al-Amarah, An-Nasiriyah and Al-Basra.

Table 5. Details of stream flow-gaging stations.

\begin{tabular}{|c|c|c|c|c|c|c|c|c|c|}
\hline \multirow{2}{*}{ Station } & \multicolumn{2}{|c|}{ Location } & \multirow{2}{*}{$\begin{array}{l}\text { Catchment } \\
\text { area up } \\
\text { station }\left(\mathbf{k m}^{2}\right)\end{array}$} & \multicolumn{2}{|c|}{ Period of record } & \multicolumn{3}{|c|}{ Discharge $\left(\mathrm{m}^{3} \cdot \mathrm{sec}^{-1}\right)$} & \multirow{2}{*}{$\begin{array}{c}\text { Average } \\
\text { yearly inflow } \\
\mathbf{K m}^{3}\end{array}$} \\
\hline & Northing & Easting & & From & To & Ave. yearly & Max. & Min. & \\
\hline Tusan $\left(\mathrm{TS}_{1}\right)$ & $37^{\circ} 04^{\prime} 00^{\prime \prime}$ & $42^{\circ} 23^{\prime} 00^{\prime \prime}$ & 46,700 & Jan. 1958 & Sep. 1975 & 666.42 & 3040 & 54.40 & 21.016 \\
\hline Zakho $\left(\mathrm{TS}_{2}\right)$ & $37^{\circ} 08^{\prime} 00^{\prime \prime}$ & $42^{\circ} 41^{\prime} 00^{\prime \prime}$ & 3500 & Nov. 1958 & Sep. 1989 & 63.84 & 413.20 & 4.37 & 2.013 \\
\hline $\operatorname{Mosul}\left(\mathrm{TS}_{3}\right)$ & $36^{\circ} 37^{\prime} 57^{\prime \prime}$ & $42^{\circ} 49^{\prime} 03^{\prime \prime}$ & 54,900 & Oct. 1931 & Sep. 2011 & 569.75 & 3514 & 87.70 & 17.96 \\
\hline Eski-kelic $\left(\mathrm{TS}_{4}\right)$ & $36^{\circ} 16^{\prime} 00^{\prime \prime}$ & $43^{\circ} 39^{\prime} 00^{\prime \prime}$ & 20,500 & Jan. 1932 & Sep. 2004 & 401 & 1781 & 33.80 & 12.646 \\
\hline Altun-Kupri $\left(\mathrm{TS}_{5}\right)$ & $35^{\circ} 45^{\prime} 41^{\prime \prime}$ & $44^{\circ} 08^{\prime} 52^{\prime \prime}$ & 15,600 & Nov. 1931 & Sep. 2004 & 221.53 & 1270 & 19.8 & 6.986 \\
\hline $\operatorname{Beiji}\left(\mathrm{TS}_{6}\right)$ & $34^{\circ} 55^{\prime} 45^{\prime \prime}$ & $43^{\circ} 29^{\prime} 35^{\prime \prime}$ & 107,600 & Apr. 1931 & Mar. 2005 & 1295.94 & 6988 & 200 & 40.87 \\
\hline Injana $\left(\mathrm{TS}_{7}\right)$ & $34^{\circ} 30^{\prime} 00^{\prime \prime}$ & $44^{\circ} 31^{\prime} 00^{\prime \prime}$ & 9840 & Oct. 1945 & Sep. 1997 & 25.48 & 423.90 & 0.00 & 0.803 \\
\hline Baghdad $\left(\mathrm{TS}_{8}\right)$ & $33^{\circ} 2 ' 34^{\prime \prime}$ & $44^{\circ} 20^{\prime} 32^{\prime \prime}$ & 134,000 & Mar. 1930 & Sep. 2009 & 979.26 & 5233 & 170.7 & 30.882 \\
\hline Diyala $\left(\mathrm{TS}_{9}\right)$ & $35^{\circ} 06^{\prime} 01^{\prime \prime}$ & $45^{\circ} 42^{\prime} 02^{\prime \prime}$ & 29,700 & Jan. 1930 & Sep. 1991 & 180.12 & 1497 & 29.50 & 5.68 \\
\hline Gharraf $\left(\mathrm{TS}_{10}\right)$ & $32^{\circ} 31^{\prime} 55^{\prime \prime}$ & $45^{\circ} 47^{\prime} 25^{\prime \prime}$ & & Dec. 1940 & Mar. 2005 & 219.89 & 495.30 & 0.00 & 6.934 \\
\hline Kut $\left(\mathrm{TS}_{11}\right)$ & $32^{\circ} 2^{\prime} 00^{\prime \prime}$ & $45^{\circ} 50^{\prime} 00^{\prime \prime}$ & 166,200 & Oct. 1931 & Sep. 2005 & 815.50 & 5792 & 65.30 & 25.72 \\
\hline Husaybah $\left(\mathrm{ES}_{1}\right)$ & $34^{\circ} 25^{\prime} 20^{\prime \prime}$ & $41^{\circ} 00^{\prime} 38^{\prime \prime}$ & 205,000 & Oct. 1973 & Sep. 1997 & 708.30 & 2760 & 85.00 & 22.34 \\
\hline Hit $\left(\mathrm{ES}_{2}\right)$ & $33^{\circ} 36^{\prime} 23^{\prime \prime}$ & $42^{\circ} 50^{\prime} 14^{\prime \prime}$ & 264,100 & Oct. 1932 & May.1997 & 802 & 5797 & 71.5 & 25.292 \\
\hline Hindiya $\left(\mathrm{ES}_{3}\right)$ & $32^{\circ} 43^{\prime} 01^{\prime \prime}$ & $44^{\circ} 16^{\prime} 01^{\prime \prime}$ & 274,100 & Oct. 1932 & Sep. 1999 & 551.62 & 3382 & 38.3 & 17.4 \\
\hline Nasiriya $\left(\mathrm{ES}_{4}\right)$ & $31^{\circ} 03^{\prime} 01^{\prime \prime}$ & $46^{\circ} 14^{\prime} 01^{\prime \prime}$ & 325,000 & Oct. 1950 & Sep. 1988 & 430 & 1810 & 29 & 13.5 \\
\hline
\end{tabular}

TS-Stream flow gaging stations on River Tigris. ES-Stream flow gaging stations on River Euphrates.

\section{Results and Discussion}

\subsection{Water Availability}

The water discharge data for stream flow gaging stations that were previously mentioned were analyzed and used to estimate the average annual reduction in the inflow due to the increase of the demand as well as the consequences of climate change. To compute reduction in the inflow; the average monthly discharge of 8 main stream flow gaging stations were used on River Tigris $\left(\mathrm{TS}_{3}, \mathrm{TS}_{6}, \mathrm{TS}_{8}\right.$ and $\left.\mathrm{TS}_{11}\right)$ and River Euphrates $\left(\mathrm{ES}_{1}, \mathrm{ES}_{2}\right.$, $\mathrm{ES}_{3}$ and $\mathrm{ES}_{4}$ ) (Figure 1). The data of these stations were used to develop the Trend lines using excel program (Figure 5). The slope of these lines were used to estimate the annual flow reduction with time (Table 6). The results showed that the percentage reduction in the inflow rate is increasing with time for both Tigris and Euphrates Rivers. The reduction steadily increases downstream the River Tigris while it oscillates downstream the 


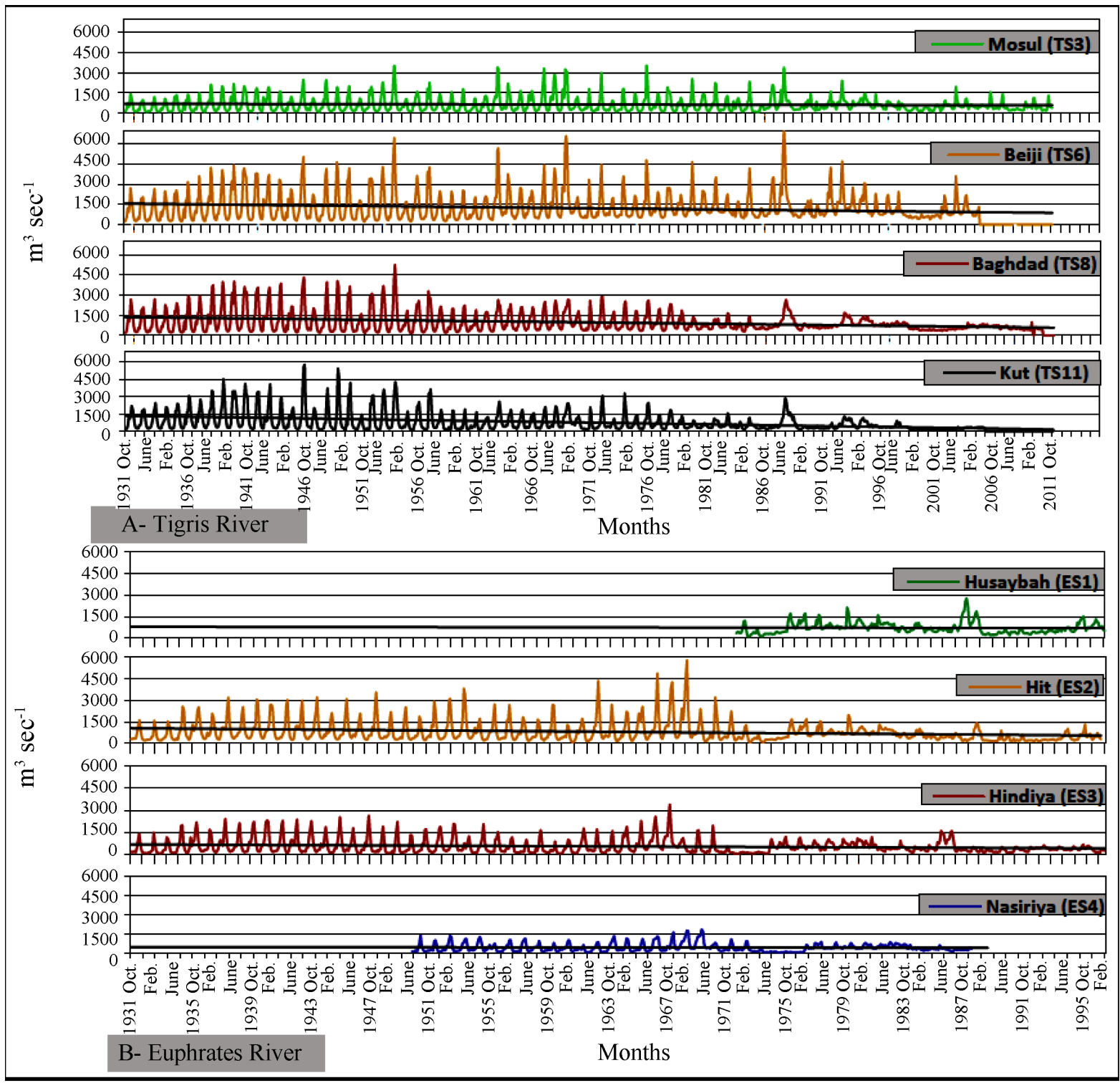

Figure 5. Average monthly inflow of Tigris-Euphrates Rivers for main stream flow gaging-station.

Table 6. Annual reductions in water inflow of main gaging stations.

\begin{tabular}{|c|c|c|c|c|c|}
\hline \multirow{2}{*}{ Station } & \multicolumn{2}{|c|}{ Average annually inflow } & \multicolumn{2}{|c|}{ Average annual water reduction } & \multirow{2}{*}{$\begin{array}{l}\text { Annual percentage } \\
\text { reduction } \%\end{array}$} \\
\hline & $\mathbf{m}^{3} \cdot \sec ^{-1}$ & $\mathbf{k m}^{3}$ & $\mathrm{~m}^{3} \cdot \sec ^{-1}$ & $\mathbf{k m}^{3}$ & \\
\hline $\operatorname{Mosul}\left(\mathrm{TS}_{3}\right)$ & 569.75 & 17.96 & 1.35 & 0.0426 & 0.2372 \\
\hline Beiji $\left(\mathrm{TS}_{6}\right)$ & 1295.94 & 40.87 & 8.64 & 0.272 & 0.666 \\
\hline Baghdad $\left(\mathrm{TS}_{8}\right)$ & 979.26 & 30.882 & 9.73 & 0.307 & 0.994 \\
\hline Kut $\left(\mathrm{TS}_{11}\right)$ & 815.50 & 25.72 & 14.73 & 0.464 & 1.804 \\
\hline Husaybah $\left(\mathrm{ES}_{1}\right)$ & 708.30 & 22.33 & 1.57 & 0.0495 & 0.222 \\
\hline Hit $\left(\mathrm{ES}_{2}\right)$ & 802 & 25.292 & 7.72 & 0.243 & 0.961 \\
\hline Hindiya $\left(\mathrm{ES}_{3}\right)$ & 551.62 & 17.40 & 4.02 & 0.127 & 0.730 \\
\hline Nasiriya $\left(\mathrm{ES}_{4}\right)$ & 430 & 13.5 & 1.452 & 0.0458 & 0.339 \\
\hline
\end{tabular}


River Euphrates. This is due to the fact that some water is diverted from Tharthar depression inside Iraq to the River Euphrates to overcome the water shortage downstream that river [15].

To find out the reduction of flow rate entering Iraq from neighboring countries, the Trend line of average monthly discharge data for station $\left(\mathrm{TS}_{1}\right)$ of the River Tigris (near Turkish-Iraqi border) was used to compute the reduction from Turkey. Stations $\left(\mathrm{TS}_{2}, \mathrm{TS}_{4}, \mathrm{TS}_{5}, \mathrm{TS}_{7}, \mathrm{TS}_{9}\right.$ and $\left.\mathrm{TS}_{10}\right)$ were used for the tributaries of the River Tigris. For the River Euphrates however, the Trend line for data station $\left(\mathrm{ES}_{1}\right)$ was used which is close to the Syrian-Iraqi border (Table 7). The results revealed that Iraq receives annually 45.4 and $25.52 \mathrm{~km}^{3}$ of water form Tigris and Euphrates respectively. River Tigris receives its water from two sources, $18.04 \mathrm{~km}^{3}$ from Turkey and $27.36 \mathrm{~km}^{3}$ from its tributaries inside Iraq.

The annual reduction of the flow of the River Euphrates was $0.245 \mathrm{~km}^{3} \cdot \mathrm{year}^{-1}$ while for the River Tigris it was $0.1335 \mathrm{~km}^{3} \cdot$ year $^{-1}\left(0.04566 \mathrm{~km}^{3}\right.$ for Turkey and $0.0879 \mathrm{~km}^{3}$ from its tributaries). The reduction of flow in the Tigris River is less than that of the River Euphrates by $0.1115 \mathrm{~km}^{3} \cdot \mathrm{year}^{-1}$. This is due to the fact that there are many dams constructed on the River Euphrates within Syria and Turkey [3] [10]. This implies the annual percentage reduction of inflow rates for Rivers Tigris and Euphrates are 0.294 and $0.960 \%$ respectively.

\subsection{Water Demand}

The water demand increases due population growth, economic development and environmental considerations. In this study the water demand for Iraq was computed using difference in the annual inflows for successive stream flow gaging stations on the Tigris-Euphrates Rivers. In some parts (downstream the last stations) it was computed depending on the population growth rates with annual water withdrawal per capita. To complete the calculations the basin was divided into 8 zones, 4 on the Tigris basin $\left(\mathrm{RT}_{1}, \mathrm{RT}_{2}, \mathrm{RT}_{3}\right.$ and $\left.\mathrm{RT}_{4}\right)$ and 4 on the Euphrates basin $\left(\mathrm{RE}_{1}, \mathrm{RE}_{2}, \mathrm{RE}_{3}\right.$ and $\left.\mathrm{RE}_{4}\right)$ depending on the location of the stream flow-gaging stations (Table 8). The differences in the annual water inflows for successive stations within these zones were used to generate the Trend lines that were used to estimate the increase in the water demand (Figure 6). The study used annual inflow for estimating the demand to reduce the error due to lag of discharge between successive stations. Furthermore, the effect of precipitation and losses due evaporation and infiltration in the sub-catchment area of these zones were automatically included with the human water consumption when using annual water discharge records of two successive gaging stations.

Figure 6 shows the annual difference rates in the water inflow of the successive stations that represents the annual water demand (water consumed) for zones $\left(\mathrm{RT}_{1}, \mathrm{RT}_{2}, \mathrm{RT}_{3}, \mathrm{RE}_{1}, \mathrm{RE}_{2}\right.$ and $\left.\mathrm{RE}_{3}\right)$. The Trend lines of the above relations showed the demand increased with time and the annual increasing rates of demand for these zones are tabulated in Table 8. The demand details for the remainder zones $\left(\mathrm{RT}_{4}\right.$ and $\mathrm{RE}_{4}$ down stations $\mathrm{TS}_{11}$ and $\mathrm{ES}_{4}$ respectively) were estimated using population growth data (Figure 4) and water withdrawal per capita for Iraq $2616 \mathrm{~m}^{3} \cdot \mathrm{year}^{-1}$ (Table 8).

The calculations results for all zones showed that the average yearly demand for Iraq is $63.05 \mathrm{~km}^{3} \cdot \mathrm{year}^{-1}$ while Iraq receives annually $70.92 \mathrm{~km}^{3} \cdot \mathrm{year}^{-1}$. The demand is shared by the two river basins where it reaches 38.10 and $24.95 \mathrm{~km}^{3} \cdot \mathrm{year}^{-1}$ for Tigris and Euphrates Rivers respectively. The overall annual increase of the demand is $1.002 \mathrm{~km}^{3} \cdot \mathrm{year}^{-1}$ (0.5271 for and $0.475 \mathrm{~km}^{3} \cdot \mathrm{year}^{-1}$ for Tigris and Euphrates basins respectively). This implies that the consumption is $88.89 \%$ of total incoming water $(60.43 \%$ and $39.57 \%$ for Rivers Tigris and Euphrates respectively).

Table 7. Water availability and inflow reductions for Tigris-Euphrates Rivers.

\begin{tabular}{|c|c|c|c|c|c|c|}
\hline & \multirow{2}{*}{ River } & \multicolumn{2}{|c|}{ Average annually inflow } & \multicolumn{2}{|c|}{ Average annual water reduction } & \multirow{2}{*}{$\begin{array}{l}\text { Annual percentage } \\
\text { reduction } \%\end{array}$} \\
\hline & & $\mathrm{m}^{3} \cdot \sec ^{-1}$ & $\mathbf{k m}^{3}$ & $\mathrm{~m}^{3} \cdot \mathrm{sec}^{-1}$ & $\mathbf{k m}^{3}$ & \\
\hline \multirow{3}{*}{ Tigris } & Turkey & 572 & 18.04 & 1.448 & 0.04566 & 0.253 \\
\hline & $\begin{array}{l}\text { Tributaries from } \\
\text { Iraq and Iran }\end{array}$ & 867.46 & 27.36 & 2.787 & 0.0879 & 0.3213 \\
\hline & Total & 1439.82 & 45.4 & 4.235 & 0.1335 & 0.294 \\
\hline Euphrates & & 802 & 25.52 & 7.777 & 0.245 & 0.960 \\
\hline Total & & 2241.81 & 70.92 & 12.012 & 0.3785 & 1.254 \\
\hline
\end{tabular}


Table 8. Water demand for Tigris-Euphrates basin in Iraq.

\begin{tabular}{|c|c|c|c|c|c|c|c|}
\hline \multirow{2}{*}{$\begin{array}{l}\text { Region } \\
\text { name }\end{array}$} & \multirow{2}{*}{$\begin{array}{l}\text { Region boundary } \\
\text { (between) }\end{array}$} & \multicolumn{2}{|c|}{ Average yearly demand } & \multicolumn{2}{|c|}{ Increasing yearly demand } & \multirow{2}{*}{$\begin{array}{l}\text { \% demand } \\
\text { from total } \\
\text { demand }\end{array}$} & \multirow{2}{*}{$\begin{array}{l}\% \text { annual } \\
\text { increasing in } \\
\text { demand }\end{array}$} \\
\hline & & $\mathrm{m}^{3} \cdot \sec ^{-1}$ & $\mathbf{k m}^{3}$ & $\mathrm{~m}^{3} \cdot \sec ^{-1}$ & $\mathbf{k m}^{3}$ & & \\
\hline $\mathrm{RT}_{1}$ & $\mathrm{TS}_{6}$--------- $\mathrm{TS}_{1}$ & 100.4 & 3.166 & 0.7 & 0.0221 & 5.02 & 0.698 \\
\hline $\mathrm{RT}_{2}$ & $\mathrm{TS}_{8}$ & 258.4 & 8.15 & 4.89 & 0.154 & 12.92 & 1.89 \\
\hline $\mathrm{RT}_{3}$ & 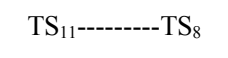 & 612.5 & 19.32 & 4.013 & 0.1265 & 30.64 & 0.655 \\
\hline $\mathrm{RT}_{4}$ & Down $\mathrm{TS}_{11}$ & 236.65 & 7.463 & 7.12 & 0.2245 & 11.84 & 3.01 \\
\hline $\mathrm{RE}_{1}$ & $\mathrm{ES}_{2}$ & 141 & 4.447 & 3.414 & 0.1077 & 7.05 & 2.422 \\
\hline $\mathrm{RE}_{2}$ & $\mathrm{ES}_{3}$---------ES ${ }_{2}$ & 331.6 & 10.46 & 4.042 & 0.127 & 16.6 & 1.214 \\
\hline $\mathrm{RE}_{3}$ & $\mathrm{ES}_{4}-------\mathrm{ES}_{3}$ & 224 & 7.06 & 4.66 & 0.147 & 11.2 & 2.081 \\
\hline $\mathrm{RE}^{4}$ & Down $\mathrm{ES}_{4}$ & 94.65 & 2.985 & 2.96 & 0.0933 & 4.73 & 3.125 \\
\hline Total & Iraq & 1999.3 & 63.05 & 28.42 & 1.002 & 100 & 1.42 \\
\hline
\end{tabular}

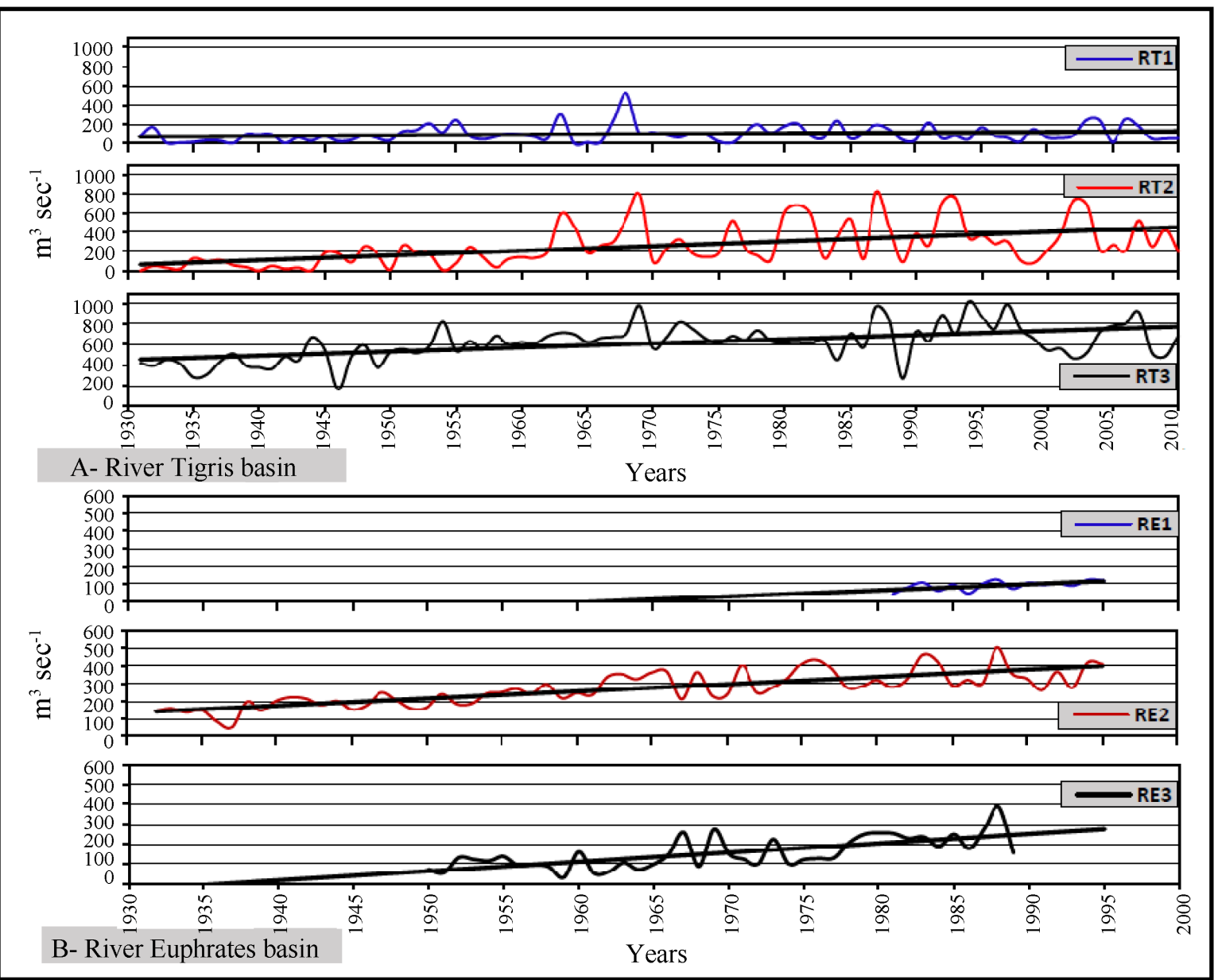

Figure 6. Average annual demand of Tigris-Euphrates Rivers basin in Iraq.

The potential water demand and water availability were compared with previous studies of Kliot [20], Kolars [21], Altinbilek [22], Beaumont [23] and UN [24] (Table 9). The results showed that the average water demand in Iraq in 2020 will increase to $72.069 \mathrm{~km}^{3} \cdot$ year $^{-1}\left(42.844 \mathrm{~km}^{3} \cdot \mathrm{year}^{-1}\right.$ for Tigris and Euphrates $29.225 \mathrm{~km}^{3} \cdot \mathrm{year}^{-1}$ 
Table 9. Potential water demand on the Tigris-Euphrates basin in Iraq for the period after 2020. (Note: Beaumont [23] used two annual water tariffs $13,300 \mathrm{~m}^{3} \cdot \mathrm{ha}^{-1}$ and $15,000 \mathrm{~m}^{3} \cdot \mathrm{ha}^{-1}$ ).

\begin{tabular}{ccccccc}
\hline River & $\begin{array}{c}\text { Kolars (1994), } \\
\left(\mathrm{km}^{3} \cdot \mathrm{year}^{-1}\right)\end{array}$ & $\begin{array}{c}\text { Kliot (1994) } \\
\left(\mathrm{km}^{3} \cdot \mathrm{year}^{-1}\right)\end{array}$ & $\begin{array}{c}\text { Altinbilek }(1997), \\
\left(\mathrm{km}^{3} \cdot \mathrm{year}^{-1}\right)\end{array}$ & $\begin{array}{c}\text { Beaumont (1998), } \\
\left(\mathrm{km}^{3} \cdot \mathrm{year}^{-1}\right)\end{array}$ & $\begin{array}{c}\text { UN }(2010), \\
\left(\mathrm{km}^{3} \cdot \mathrm{year}^{-1}\right)\end{array}$ & $\begin{array}{c}\text { Current study, } \\
\left(\mathrm{km}^{3} \cdot \mathrm{year}^{-1}\right)\end{array}$ \\
\hline Tigris & 29.20 & 40.00 & 31.90 & 38.2 to 61.0 & ---- & 42.844 \\
Euphrates & 17.00 & 16.00 & 15.50 & 25 to 28.1 & - --- & 29.225 \\
Total & 46.20 & 46.00 & 47.4 & 58.2 to 89.1 & 77 & 72.069 \\
\hline
\end{tabular}

respectively). On the contrary, the amount of available water will decrease to $63.46 \mathrm{~km}^{3} \cdot \mathrm{year}^{-1}(44.06$ $\mathrm{km}^{3} \cdot \mathrm{year}^{-1}$ and $19.40 \mathrm{~km}^{3} \cdot \mathrm{year}^{-1}$ for Tigris and Euphrates respectively). The total water deficit of Tigris-Euphrates Rivers basin will be $8.61 \mathrm{~km}^{3} \cdot \mathrm{year}^{-1}$. Water shortages will be of $9.83 \mathrm{~km}^{3}$ on the Euphrates River basin at 2020. On the contrary the Tigris River will experience a surplus of $1.221 \mathrm{~km}^{3}$ (Table 9). These figures are calculated assuming that there will be no dams constructed on both rivers in future. In case these are considered then the water availability after 2025 will be 9.16 and $8.45 \mathrm{~km}^{3}$ for Tigris and Euphrates respectively (UN, 2010). In addition, restoring the marshes was not considered.

\section{Summary and Conclusion}

The average monthly inflows for 15 stream flow gaging stations on the Rivers Tigris and Euphrates inside Iraq were used to estimate water availability and its rate of reduction. Furthermore, these data with population growth and water consumption per capita were used to compute the demand and its increase. The results showed that the total water availability in Iraq from these rivers is $70.92 \mathrm{~km}^{3} \cdot \mathrm{year}^{-1}$ of which are $45.4 \mathrm{~km}^{3} \cdot \mathrm{year}^{-1}$ and $25.52 \mathrm{~km}^{3} \cdot \mathrm{year}^{-1}$ for Tigris and Euphrates Rivers, respectively. Iraq receives annually an average of 18.04 $\mathrm{km}^{3} \cdot \mathrm{year}^{-1}$ of water at the Turkish-Iraqi border from the River Tigris. Inside Iraq, the tributaries of the River Tigris supply another $27.36 \mathrm{~km}^{3} \cdot \mathrm{year}^{-1}$ annually. The rate of reduction of inflow for River Tigris is 0.1335 $\mathrm{km}^{3} \cdot \mathrm{year}^{-1}(0.294 \%)$ which is less than Euphrates $0.245 \mathrm{~km}^{3} \cdot \mathrm{year}^{-1}(0.961 \%)$ The average water demand in Iraq is $63.05 \mathrm{~km}^{3} \cdot \mathrm{year}^{-1}$. About $38.1 \mathrm{~km}^{3} \cdot \mathrm{year}^{-1}$ is for the River Tigris basin and $24.95 \mathrm{~km}^{3} \cdot \mathrm{year}^{-1}$ is for the Euphrates basin. The rate of demand in Iraq is increasing annually by $1.002 \mathrm{~km}^{3} \cdot \mathrm{year}^{-1}\left(0.5271 \mathrm{~km}^{3} \cdot \mathrm{year}^{-1}\right.$ for Tigris River basin and $0.475 \mathrm{~km}^{3} \cdot \mathrm{year}^{-1}$ for Euphrates basin). In addition, the water inflow at 2020 will decrease to $63.46 \mathrm{~km}^{3} \cdot \mathrm{year}^{-1}$ and the demand will increase to $72.069 \mathrm{~km}^{3} \cdot \mathrm{year}^{-1}$.

\section{Acknowledgements}

The research presented has been financially supported by Luleå University of Technology, Sweden and by "Swedish Hydropower Centre-SVC" established by the Swedish Energy Agency, Elforsk and Svenska Kraftnät together with Luleå University of Technology, The Royal Institute of Technology, Chalmers University of Technology and Uppsala University. Their support is highly appreciated.

\section{References}

[1] Naff, T. (1994) Conflict and Water Use in the Middle East. In: Rogers, P. and Lydon, P., Eds., Water in the Arab World: Perspectives and Prognoses, Harvard University Press, Boston, 253-284.

[2] Al-Ansari, N.A. (1998) Water Resources in the Arab Countries: Problems and Possible Solutions. UNESCO International Conference on Water: A Looming Crisis, Paris, 367-376.

[3] Al-Ansari, N.A. (2013) Management of Water Resources in Iraq: Perspectives and Prognoses. Journal of Engineering, 5, 667-684. http://dx.doi.org/10.4236/eng.2013.58080

[4] Altinbilek, D. (2004) Development and Management of the Euphrates-Tigris Basin. Water Resources Development, 20, 15-33. http://dx.doi.org/10.1080/07900620310001635584

[5] World Bank (2006) Iraq: Country Water Resources, Assistance Strategy: Addressing Major Threats to People's Livelihoods. Report No. 36297-IQ, 1-97.

[6] Droogers, P., Immerzeel, W.W., Terink, W., Hoogeveen, J., Bierkens, M.F.P., van Beek, L.P.H. and Debele, B. (2012) Water Resources Trends in Middle East and North Africa towards 2050. Hydrology and Earth System Sciences, 16, 3101-3114. http://dx.doi.org/10.5194/hess-16-3101-2012 
[7] Voss, K.A., Famiglietti, J.S., Lo, M., de Linage, C., Rodell, M. and Swenson, S.C. (2013) Groundwater Depletion in the Middle East from GRACE with Implications for Trans Boundary WATER Management in the Tigris-Euphrates Western Iran Region. Water Resource Research, 49, 904-914. http://dx.doi.org/10.1002/wrcr.20078

[8] UNEP (2001) The Mesopotamian Marshlands: Demise of an Ecosystem. Early Warning and Assessment Technical Report no. 3, UNEP/DEWA/TR.01-3 (Geneva: UNEP).

[9] Iraqi Ministry of Water Resources "Water Resources, Mosul Dam”. http://www.mowr.gov.iq/cwaterresourceview.php?id=54

[10] Al-Ansari, N.A. and Knutsson, S. (2011) Toward Prudent Management of Water Resources in Iraq. Journal of Advanced Science and Engineering Research, 1, 53-67.

[11] Al-Ansari, N.A., Sayfy, A., Al-Sinawi, G.T. and Ovanessian, A.A. (1986) Evaluation of the Water Quality for the Lower Reaches of River Tigris Using Multivariate Analysis. Journal of Water Resources, 5, 173-187.

[12] Najib, Y.E. (1980) Characteristics of Tigris River at Mosul. MSc Thesis, College of Engineering, University of Mosul, Mosul.

[13] Biedler, M. (2004) Hydropolitics of the Tigris-Euphrates River Basin with Implications for the European Union. CERIS Centre Européen de Recherche Internationale et Stratégique, Research Papers No. 1, 1-44.

[14] Al-Ansari, N.A., Barazanji, A., Al-Jabari, M. and Gayara, A. (1981) Geological Investigation of Mosul Dam Site. Report submitted to the Ministry of Irrigation, Iraq, 41p.

[15] Al-Ansari, N.A., Assad, N., Walling, D.E. and Hussan, S.A. (1988) The Suspended Sediment Discharges of River Euphrates at Haditha, Iraq. Geografisca Annaler, 79A, 203-213. http://dx.doi.org/10.2307/521072

[16] Al-Shahrabaly, K.M. (1989) Rivers Water Discharges Passing in the Main Gaging-Stations on the Tigris-Euphrates Rivers. Iraq Ministry of Agriculture and Irrigation, $119 \mathrm{p}$.

[17] Saleh, D.K. (2010) Stream Gage Descriptions and Stream Flow Statistics for Sites in the Tigris River and Euphrates River Basins, Iraq. US Department of the Interior, U.S. Geological Survey, Data series 540, 1-154. http://pubs.usgs.gov/ds/540/pdf/ds540.pdf

[18] City Population (2013) Population Statistics for Countries, Administrative Areas, Cities and Agglomerations-Inter active Maps - Charts. http://www.citypopulation.de/Iraq.html\#Stadt alpha.

[19] Country Fact Sheet, AQUASTAT Survey Iraq. Food and Agriculture Organization of the United Nations. http://www.fao.org/nr/water/aquastat/data/cf/readPdf.html?f=CF IRQ en.pdf

[20] Kliot, N. (1994) Water Resources and Conflict in the Middle-East. Routledge, London.

[21] Kolars, J. (1994) Problems of International River Management: The Case of the Euphrates. In: Biswas, A.K., Ed., International Water of Middle East from Euphrates-Tigris to Nile. Water Resources Management Series 2, Oxford University Press, Oxford, 45-94.

[22] Altinbilek, H.D. (1997) Water and Land Resources Development in Southeastern Turkey. Journal of Water Resources Development, 13, 311-332. http://dx.doi.org/10.1080/07900629749719

[23] Beaumont, P. (1998) Restructuring of Water Usage in the Tigris-Euphrates Basin: The Impact of Modern Water Management Policies. Yale School of Forestry and Environmental Studies, Bulletin Series, 103, 168-186.

[24] United Nations (2010) Water Resources Management White Paper. United Nations Assistance Mission for Iraq, United Nations Country Team in Iraq, 20 p. 